\title{
GLUTAMATERGIC DRUGS IN PARKINSON'S DISEASE
}

\author{
Klaus W. Lange and Peter Riederer \\ Laboratory of Clinical Neurochemistry, \\ University of Würzburg, Würzburg, Germany
}

\begin{abstract}
Bummary
Recent findings in monkeys indicate that excitatory amino acids such as glutamate are involved in the pathophysiological cascade of MPTP (1-methyl-4-phenyl$1,2,3,6$-tetrahydropyridine)-induced neuronal cell death. The neuroprotective effects of competitive and noncompetitive NMDA (N-methyl-D-aspartate) antagonists against MPTP toxicity support the hypothesis that NMDA receptor-mediated events are involved in the neurotoxicity of MPTP. These results suggest that the clinical trial of NMDA antagonists in patients with Parkinson's disease should be performed. Further evidence obtained in animal models of Parkinson's disease indicates that both competitive NMDA antagonists and AMPA (alpha-amino-3hydroxy-5-methyl-4-isoxazolepropionate) antagonists show symptomatic anti-parkinsonian activity in combination with L-DOPA. Glutamate antagonists may therefore retard the progression and improve the symptomatology of Parkinson's disease. The 1-amino-adamantanes amantadine and memantine have recently been shown to be non-competitive NMDA antagonists and are widely used in Europe as antiparkinsonian agents. Both compounds are likely to cause pharmacotoxic psychosis as an unwanted side-effect. Clinical trials are needed to test the efficacy of the 1amino-adamantanes with respect to the progression of Parkinson's disease.
\end{abstract}

Key Words: glutamate, glutamate antagonists, Parkinson 's disease, akinesia, MPTP, neuroprotection

The biochemical changes observed in the substantia nigra of patients with Parkinson's disease such as impaired mitochondrial function, altered iron metabolism and increased lipid peroxidation emphasize the significance of oxidative stress and free radical formation in the pathogenesis of the disease ( 1 , see Table 1). Protection against such oxidative damage could be provided by scavengers of free radicals and anti-oxidants such as monoamine oxidase type $B$ (MAO-B) inhibitors, alpha-tocopherol (vitamin E), ascorbic acid (vitamin C) and iron chelators.

Correspondence to $\mathrm{Dr}$. K. W. Lange, Department of Psychiatry, University of Würzburg, Füchsleinstr. 15, 97080 Würzburg, Germany 


\section{Table 1}

Neuroprotective strategies in Parkinson's disease

Biochemical alterations in the substantia nigra
Possible neuroprotective therapies

\author{
Formation of hydrogen peroxide \\ Increased iron content \\ Formation of toxic oxygen \\ free radicals \\ Alteration in the homeostasis \\ of intracellular calcium \\ Excess activity of \\ excitatory amino acids (?)
}

\author{
MAO-B inhibitors \\ (e.g. L-deprenyl) \\ Iron chelators \\ Free radical scavengers \\ (e.g. vitamins $C$ and $E$ ) \\ Calcium entry blockers \\ (e.g. nimodipine) \\ Excitatory amino acid \\ antagonists
}

\section{Excitatory amino acids and neurodegeneration}

The amino acid L-glutamate is the major excitatory neurotransmitter in the mammalian central nervous system (2) and gates cationic channels that mediate fast excitatory synaptic responses. These channels also mediate neuronal death following excessive glutamate release in the central nervous system secondary to acute pathological events such as stroke and head trauma (see Table 2). Excessive activity of excitatory amino acids has been postulated to play a role in a variety of neurodegenerative diseases including Parkinson's disease (3). This hypothesis is based on findings showing neurotoxic properties of both L-glutamate (4) and substances exciting the main ionotropic glutamate receptor subtypes, i.e. N-methyl-Daspartate (NMDA), alpha-amino-3-hydroxy-5-methyl-4isoxazolepropionate (AMPA) and kainate. The channels intrinsic to all subtypes conduct $\mathrm{Na}^{+}$, NMDA-gated channels also possess $\mathrm{Ca}^{2+}$ conductivity that may play a role in neuronal plasticity and neurotoxicity. Microinjections of many excitatory amino acids into various brain areas can produce an acute reaction that selectively destroys certain neurones in the area $(5,6)$.

\section{Table 2}

Pathological roles of glutamate

Epileptogenesis

Acute neuropathological changes

$\begin{array}{ll}\text { Hypoxia, } & \text { Stroke, } \\ \text { Hypoglycemia, } & \text { Trauma, } \\ \text { Exogenous toxins } & \end{array}$

Hypoglycemia,

Chronic neuropathological changes

$\begin{array}{ll}\text { Alzheimer's disease, } & \text { Huntington's disease, } \\ \text { Parkinson's disease, } & \text { Motoneuron disease }\end{array}$ 


\section{Excitatory amino acids and MPTP neurotoxicity}

There is evidence indicating that excitatory amino acids are involved in the neurotoxic effects of MPTP. Systemic administration of MPTP to humans and non-human primates causes parkinsonian motor deficits associated with a selective destruction of dopamine-containing neurones in the substantia nigra pars compacta and a marked reduction in striatal dopamine content $(7.8,9,10)$. Neurotoxicity appears to be due to the formation of 1-methyl-4-phenylpyridinium ion $\left(\mathrm{MPP}^{+} ; 11,12,13\right)$ which is the result of the conversion of MPTP by MAO-B into the dihydropyridinium species $\left(\mathrm{MPDP}^{+}\right)$which is converted nonenzymatically into $\mathrm{MPP}^{+}$. This compound is subsequently transported by the dopamine uptake process to accumulate within dopaminergic neurones and to be temporarily stored in a releasable pool (14, 15). The toxicity of $\mathrm{MPP}^{+}$apparently occurs as the result of intraneuronal uptake by a mitochondrial carrier and inhibition of complex I of the mitochondrial respiratory chain (16).

Excitatory amino acids such as glutamate appear to be involved in the pathophysiological cascade of MPTP/MPP ${ }^{+}$-induced neuronal death. It has been shown that $\mathrm{MPP}^{+}$causes a release of glutamate and aspartate in the rat brain (17). Gutamate antagonists, which competitively or non-competitively block the NMDA subtype of receptor, protect dopaminergic nigral neurones against destruction by $\mathrm{MPP}^{+}$injected directly into the substantia nigra pars compacta (SNC) of rats (18). Since rats are less sensitive to $\mathrm{MPP}^{+}$than primates, the doses of the toxin needed to produce brain damage are very high and could cause unspecific toxic effects (19). In the mouse, the non-competitive NMDAreceptor antagonist (+)-5-methyl-10,11-dihydro-5Hdibenzo[a,d]cyclo-hepten-5,10-imine maleate $(\mathrm{MK}-801)$ has been shown to be ineffective in preventing the dopamine depletion induced by systemic administration of $\operatorname{MPTP}(20,21)$. Recent studies in monkeys, however, have demonstrated that glutamate antagonists are able to modulate the neurotoxicity of MPTP. The competitive NMDA antagonist 3-(( \pm )-2-carboxypiperazin-4-yl)propyl-1-phosphonic acid (CPP) protects tyrosine hydroxylase (TH)-positive neurones in the substantia nigra from degeneration induced by systemic treatment with MPTP in the common marmoset (22). The non-competitive NMDA antagonist MK-801 prevents the development of the parkinsonian syndrome in the cynomolgus monkey (23) and protects nigral tyrosine hydroxylase-positive neurones in cynomolgus monkeys (23) and marmosets (24) from degeneration following the administration of MPTP. The neuroprotective action of competitive and non-competitive NMDA receptor antagonists against MPTP toxicity (see Table 3 ) supports the hypothes is that NMDA receptor-mediated events are involved in the neurotoxicity of MPTP and $\mathrm{MPP}^{+}$. MPP ${ }^{+}$interferes with mitochondrial respiration and depletes cell energy resources (16). Neuronal energy deprivation could alter the normal functioning of cell membranes and cause a partial depolarization leading to a release of the voltage dependent $\mathrm{Mg}^{2+}$ block of NMDA receptor ion channels (25). Removal of the $\mathrm{Mg}^{2+}$ block enables excitatory amino acids to excite their receptors persistently, to open the ion channels and to become neurotoxic (26). 


\section{Table 3}

Anti-glutamatergic neuroprotection following MPTP/MPP ${ }^{+}$administration

\begin{tabular}{|c|c|c|c|}
\hline Species & $\begin{array}{l}\text { MPTP/MPP }{ }^{+} \\
\text {administration }\end{array}$ & $\begin{array}{l}\text { Glutamate } \\
\text { antagonist }\end{array}$ & $\begin{array}{l}\text { Neuroprotective } \\
\text { effects }\end{array}$ \\
\hline Mouse & $\begin{array}{l}\text { MPTP } 20 \mathrm{mg} / \mathrm{kg}, \\
2 \text {-hourly, } \\
4 \text { times, i.p. }\end{array}$ & $\begin{array}{l}\text { MK-801 } 2.5 \mathrm{mg} / \mathrm{kg} \text {, } \\
3-\text { hourly, twice, } \\
\text { i.p. }\end{array}$ & $\begin{array}{l}\text { Partial protection } \\
\text { against neostriatal } \\
\text { dopamine reduction } \\
\text { and no protection } \\
\text { against reduced neo- } \\
\text { striatal TH activity } \\
3 \text { days after MPTP } \\
(20)\end{array}$ \\
\hline Mouse & $\begin{array}{l}\text { MPTP } 20 \mathrm{mg} / \mathrm{kg}, \\
2 \text {-hourly, } \\
4 \text { times, i.p. }\end{array}$ & $\begin{array}{l}\text { MK-801 } 2.5 \mathrm{mg} / \mathrm{kg}, \\
4 \text {-hourly, } 6 \text { times } \\
\text { i.p. }\end{array}$ & $\begin{array}{l}\text { No protection } \\
\text {, against neostriatal } \\
\text { dopamine reduction } \\
1 \text { week after MPTP } \\
\text { (21) }\end{array}$ \\
\hline Rat & $\begin{array}{l}\mathrm{MPP}^{+} \text {focally } \\
\text { into SNC }\end{array}$ & $\begin{array}{l}\mathrm{CPP} 0.1 \mathrm{mmol} / \mathrm{kg}, \\
\mathrm{MK}-8010.01 \mathrm{mmol} \\
\mathrm{kg}, 4 \text {-hourly, } \\
6 \text { times, i.p. }\end{array}$ & $\begin{array}{l}\text { Protection against } \\
\text { neuronal loss in SNC } \\
24 \text { hours and } 7 \text { days } \\
\text { after } \mathrm{MPP}^{+}(18)\end{array}$ \\
\hline Rat & $\begin{array}{l}\mathrm{MPP}^{+} \text {focally } \\
\text { into SNC }\end{array}$ & $\begin{array}{l}\text { MK-801 } 2.2 \mathrm{mg} / \mathrm{kg}, \\
4-\text { hourly, } 6 \text { times, } \\
\text { i.p. }\end{array}$ & $\begin{array}{l}\text { No protection } \\
\text { against nigral cell } \\
\text { loss } 7-11 \text { days after } \\
\text { MPP }^{+}(21)\end{array}$ \\
\hline $\begin{array}{l}\text { Common } \\
\text { marmoset }\end{array}$ & $\begin{array}{l}\text { MPTP } 6 \mathrm{mg} / \mathrm{kg} \text {, } \\
\text { once, } \mathrm{s} . \mathrm{C} \text {. }\end{array}$ & $\begin{array}{l}\text { CPP } 25 \mathrm{mg} / \mathrm{kg}, \\
4 \text {-hourly, } 48 \text { hrs, } \\
\text { i.p. }\end{array}$ & $\begin{array}{l}\text { Protection of } \mathrm{TH}- \\
\text { positive neurons in } \\
\text { substantia nigra } \\
\text { (22) }\end{array}$ \\
\hline $\begin{array}{l}\text { Common } \\
\text { marmoset }\end{array}$ & $\begin{array}{l}\text { MPTP } 2 \mathrm{mg} / \mathrm{kg}, \\
\text { daily, } 5 \text { days, } \\
\text { s.c. }\end{array}$ & $\begin{array}{l}\text { MK- } 801 \mathrm{mg} / \mathrm{kg} \\
4-\text { hourly, } 7 \text { days, } \\
\text { s.c. }\end{array}$ & $\begin{array}{l}\text { Protection of nigral } \\
\text { TH-positive neurons } \\
\text { and of neostriatal } \\
{\left[{ }^{3} \mathrm{H}\right] \text { mazindol binding }} \\
\text { sites } 7 \text { days after } \\
\text { start of treatment } \\
\text { (24) }\end{array}$ \\
\hline $\begin{array}{l}\text { Cynomolgus } \\
\text { monkey }\end{array}$ & $\begin{array}{l}\text { MPTP } 0.36 \mathrm{mg} / \mathrm{kg} \\
7 \text { times a day } \\
\text { for } 5 \text { days, } \\
\text { i.v. }\end{array}$ & $\begin{array}{l}\text { MK }-8010.01 \mathrm{mg} / \mathrm{kg} \\
7 \text { times a day } \\
\text { for } 5 \text { days, } \\
\mathrm{i} . \mathrm{v} .\end{array}$ & $\begin{array}{l}\text { Partial protection } \\
\text { against neostriatal } \\
\text { dopamine reduction } \\
\text { and protection of } \\
\text { nigral TH-positive } \\
\text { cells } 12 \text { days after } \\
\text { start of treatment } \\
\text { (23) }\end{array}$ \\
\hline
\end{tabular}




\section{Excitatory amino acids and parkinsonism}

The neurotoxic effects of excitatory amino acids may be involved in the pathogenesis of Parkinson's disease (27). Other forms of parkinsonism have been linked with dietary consumption of toxic excitatory amino acids acting on dopaminergic cells in the substantia nigra. The amino acid $B-N-m e t h y l a m i n-L-a l a n i n e$ (BMAA) contained in flour made from the cycad cycas circinalis has been proposed to be the cause of the amyotrophic lateral sclerosis-parkinsonism-dementia syndrome occurring in Guam and other south sea islands (28). The excitotoxicity of BMAA can be blocked by AP5 or AP7, indicating an action on NMDA receptors (29). Concussive brain injuries are associated with increased extracellular excitatory amino acid concentrations (30) and can cause nigrostriatal degeneration and parkinsonism in boxers with dementia pugilistica (31).

The findings demonstrating neuroprotective effects of competitive and non-competitive NMDA antagonists in MPTP-treated monkeys suggest that the clinical trial of NMDA antagonists in patients with Parkinson's disease should be performed. The 1amino-adamantanes amantadine and memantine, which are in use as anti-parkinsonian drugs, have been shown to be non-competitive NMDA antagonists (32). Memantine displaces $\left[{ }^{3} \mathrm{H}\right]-\mathrm{MK}-801$ in binding studies $(32,33)$ and has non-competitive NMDA antagonistic properties in functional models $(34,35)$. Whether or not these compounds have neuroprotective properties and whether they may be able to delay the progression of Parkinson's disease is unknown. If neuroprotective effects of NMDA antagonists can be shown in humans, then a novel strategy for the neuroprotective or even preventive therapy of Parkinson's disease could be available.

\section{Excitatory amino acids and akinesia}

The loss of dopamine in the striatum as a result of the neuronal degeneration in the substantia nigra pars compacta has been thought to be the major pathochemical correlate of the main symptoms of Parkinson's disease such as akinesia and rigidity (36). The discovery of dopaminergic deficiency in the basal ganglia led to the use of replacement therapies including L-DOPA treatment, dopaminergic agonists and the selective MAO-B inhibitor L-deprenyl. Dopamine has been shown in recent animal studies to be of less importance in the regulation of psychomotor functions than was previously believed. For example, a pronounced locomotor stimulation can be produced in mice depleted of monoaminergic stores following suppression of glutamatergic neurotransmission $(37,38)$. This finding raises the question of whether glutamatergic mechanisms are involved in the regulation of locomotor activity and in the motor symptoms observed in Parkinson's disease.

There is increasing evidence that the dopaminergic nigrostriatal system and the strio-nigral GABA/substance $P$ system are only one part of a motor loop system which is formed by the basal ganglia and the motor thalamus and receives information from wide cortical areas and projects to distinct premotor cortical areas (39). The degeneration of the dopaminergic nigro-striatal pathway 
in Parkinson's disease results in profound changes within this motor loop.

Both electrophysiological and neurochemical studies in MPTPtreated parkinsonian monkeys suggest that secondary increases of glutamatergic neurotransmission in the subthalamic nucleus, medial segment of the globus pallidus and substantia nigra pars reticulata are essential steps in the evolution of parkinsonian symptoms $(40,41)$. Enhanced glutamatergic activity is assumed to occur in the subthalamic nucleus due to a decreased GABAergic input from the lateral globus pallidus. Hyperactivity of the glutamatergic projection neurones in the subthalamic nucleus enhances activity in the basal ganglia output nuclei, i.e. the substantia nigra pars reticulata and the internal segment of the globus pallidus. The consequence of these alterations is a pathological degree of tonic activity in the basal ganglia output system directed to the motor thalamus and brainstem (42). This simplified model of basal ganglia pathophysiology in Parkinson's disease suggests that anti-glutamatergic drugs may be of therapeutic benefit. Lesion of the subthalamic nucleus by focal injection of the neurotoxin ibotenic acid ameliorates parkinsonian symptoms in MPTP-treated green monkeys (40). The glutamate antagonist kynurenate reverses akinesia in the MPTPtreated common marmoset following focal injection into the medial pallidum (43). These findings indicate that the selective reduction of glutamatergic overactivity may be an effective strategy for the treatment of Parkinson's disease.

The validity of the concept of glutamatergic hyperactivity in Parkinson's disease and the potential for anti-glutamatergic therapy are underlined by studies with rodents demonstrating that the non-competitive NMDA antagonist MK-801 (dizocilpine) stimulates locomotor activity in monoamine-depleted mice (37) and rats (44) and reverses neuroleptic-induced catalepsy in rats (45, 46). The AMPA antagonist NBQX (6-nitro-7-sulfamoylbenzo[f]quinoxaline-2,3-dione) potentiates the action of L-DOPA in reserpinized rats (47) and in the 6-OHDA circling model (48). Initial experiments with monkeys rendered parkinsonian with MPTP failed to demonstrate an anti-parkinsonian action of MK-801 (49, 50). Subsequent experiments with MPTP-treated common marmosets, however, showed that both the competitive NMDA receptor antagonist CPP and the quisqualate receptor antagonist NBQX increase locomotor activity when administered with a threshold dose of L-DOPA $(47,48)$.

Since the glutamatergic thalamo-cortical tract appears to be underactive in Parkinson's disease (40), systemic administration of glutamate antagonists should aggravate parkinsonian symptoms. This is probably reflected in the reduction of locomotor activity observed in MPTP-treated monkeys following NBQX administered alone (48). However, the massive increase in locomotor activity obtained following the administration of L-DOPA plus NBQX or CPP (48) imply that stimulation of the deficient dopaminergic pathways in combination with inhibition of the glutamatergic systems has clear synergistic effects on locomotor activity.

These findings in animal models of Parkinson's disease suggest that glutamate antagonists may be of benefit in the treatment of patients with the disease. A combined therapy with 
L-DOPA and glutamate antagonists should allow a reduction of the L-DOPA dose and may postpone or prevent side-effects of long-term L-DOPA administration (51).

The only anti-glutamatergic drugs available for the treatment of Parkinson's disease are the non-competitive NMDA receptor antagonists amantadine and memantine, which have moderate anti-akinetic efficacy compared to dopamimetic substances (52). The action of memantine at the NMDA receptor might well explain its anti-parkinsonian activity, since the $K_{i}$ value of memantine is lower than the brain concentration reached in the treatment of Parkinson's disease $(32,53)$. The finding that the $K_{i}$ value of amantadine is about 20 times higher than that of memantine is compatible with the clinical experience that the mean daily dose of amantadine in the treatment of Parkinson's disease is about 5-10 times higher than that of memantine.

Decreased glutamatergic function has been postulated to be a significant factor in the pathophysiology of schizophrenia (54). Anti-glutamatergic treatment of Parkinson's disease carries therefore the risk of psychotic side-effects. Amantadine is known to have mild anti-akinetic effects in parkinsonian patients and psychosis is a frequent adverse reaction (52). The occurrence of pharmacotoxic psychosis has been examined following administration of memantine in patients with Parkinson's disease (55). Parkinsonian subjects received memantine in addition to their usual anti-parkinsonian medication. Only one patient showed a mild improvement of his motor symptoms. The other three patients did not benefit from additional memantine administration. In two out of these three, however, memantine produced psychosis. Memantine administered in doses producing little or no anti-parkinsonian effects appears to be likely to cause pharmacotoxic psychosis. Whether or not competitive NMDA antagonists or non-NMDA antagonists have similar side-effects remains to be examined in clinical trials. Because of possibly severe side-effects of glutamatergic antagonists in the treatment of akinesia, the development of partial glutamate antagonists could be an alternative strategy capable of producing antiakinetic effects with only mild adverse reactions.

\section{Acknowledgment}

This work was supported by a grant (No. $01 \mathrm{KL} 9013$ ) from the German Federal Ministry of Research and Technology, Bonn.

\section{References}

1. K.W. LANGE, M.B.H. YOUDIM and P. RIEDERER, J. Neural Transm. Suppl. 38 27-44 (1992).

2. F. FONNUM, J. Neurochem. 42 1-11 (1984).

3. J.W. OLNEY, Drug Dev. Res. 17 299-319 (1989).

4. J.W. OLNEY, Science $164719-721$ (1969).

5. E.G. MCGEER, J.W. OLNEY and P.L. MCGEER, Kainic ACid as a Tool in Neurobiology, Raven Press, New York (1978).

6. S.M. ROTHMAN and J.W. OLNEY, Trends Neurosci. 10 299-302 (1987). 
7. G.C. DAVIS, A.C. WILLIAMS, S.P. MARKEY, M.H. EBERT, E.D. CAINE, C.M. REICHERT and I.J. KOPIN, Psychiat. Res. 1 249-254 (1979).

8. J.W. LANGSTON, P. BALLARD, J.W. TETRUD and I. IRWIN, Science 219 979-980 (1983).

9. J.W. LANGSTON, L.S. FORNO, C.S. REBERT and I. IRWIN, Brain Res. 292 390-394 (1984).

10. R.S. BURNS, C.C. CHIUEH, S.P. MARKEY, M.H. EBERT, D.M. JACOBOWITZ and I.J. KOPIN, Proc. Natl. Acad. Sci. U.S.A. $\underline{80}$ 4546-4550 (1983).

11. A. CASTAGNOLI JR., K. CHIBA and A.J. TREVOR, Life Sci. 36 225-230 (1985).

12. J.R. SANCHEZ-RAMOS, P. MICHEL, W.J. WEINER and F. HEFTI, J. Neurochem. 50 1934-1936 (1988).

13. K.W. LANGE, Eur. J. Pharmacol. 175 57-61 (1990).

14. J.A. JAVITCH, R.J. D'AMATO, S.M. STRITTMATTER and S.H. SNYDER, Proc. Natl. ACad. Sci. U.S.A. 82 2173-2177 (1985).

15. S. SCHINELLI, A. ZUDDAS, I.J. KOPIN, J.L. BARKER and U. DI PROZIO, J. Neurochem. $\underline{50}$ 1900-1907 (1988).

16. W.J. NICKLAS, L. VYAS and R.E. HEIKKILA, Life Sci. 36 25032508 (1985).

17. S. CARBONI, F. MELIS, L. PANI, M. HADJICONSTANTINOU and $\mathrm{z}$. ROSETTI, Neurosci. Lett. 117 129-133 (1990).

18. L. TURSKI, K. BRESSLER, K.-J. RETTIG, P.-A. LÖSCHMANN and H. WACHTEL, Nature 349 414-418 (1991).

19. S.I. HARIK, J.W. SCHMUDLEY, L.A. IACOFANO, P. BLUE, P.K. ARORA and L.M. SAYRE, J. Pharm. Exp. Therap. 241 669-676 (1987).

20. P.K. SONSALLA, W.J. NICKLAS and R.E. HEIKKILA, Science 243, 398-400 (1989).

21. P.K. SONSALLA, G.D. ZEEVALK, L. MANZINO, A. GIOVANNI and W.J. NICKLAS, J. Neurochem. 58 1979-1982 (1992).

22. K.W. LANGE, P.-A. LÖSCHMANN, E. SOFIC, M. BURG, R. HOROWSKI, K.T. KALVERAM, H. WACHTEL and P. RIEDERER, NaunynSchmiedeberg's Arch. Pharmacol. (in press).

23. A. ZUDDAS, G. OBERTO, F. VAGLINI, F. FASCETTI, F. FORNAI and G.U. CORSINI, J. Neurochem. 59 733-739 (1992).

24. K.W. LANGE, unpublished data.

25. L. NOWAK, P. BREGESTOVSKI, P. ASCHER, A. HERBET and A. PROCHIANTZ, Nature 307 462-465 (1984).

26. A. NOVELLI, J.A. REILLY, P.G. LYSKO and R.C. HENNEBERRY, Brain Res. 451 205-212 (1988).

27. D.B. CALNE, A. EISEN, E. MCGEER and P. SPENCER, Lancet II 1067-1070 (1986).

28. P.S. SPENCER, P.B. NUNN, J. HUGON, A.C. LUDOLPH, S.M. ROSS, D.N. ROY and R.C. ROBERTSON, Science 237 517-522 (1987).

29. J.H. WEISS and D.W. CHOI, Science 241 973-975 (1988).

30. A.I. FADEN, P. DEMEDIUK, S.S. PANTER and R. VINK, Science 244 798-800 (1989).

31. C. MAWDSLEY and F.R. FERGUSON, Lancet II 795-801 (1963).

32. J. KORNHUBER, J. BORMANN, M. HÜBERS, K. RUSCHE and P. RIEDERER, Eur. J. Pharmacol. (Mo1. Pharmacol. Sect.) 206 297-300 (1991).

33. J. KORNHUBER, F. MACK-BURKHARDT, P. RIEDERER, G.F. HEBENSTREIT, G.P. REYNOLDS, H.B. ANDREWS and H. BECKMANN, J. Neural Transm. 77, 231-236 (1989).

34. J. BORMANN, Eur. J. Pharmacol. $\underline{166} 591-592$ (1989).

35. A. LUPP, C.H. LÜCKING, R. KOCH, R. JACKISCH and T.J. FEUERSTEIN, J. Pharmacol. Exp. Ther. $\underline{263} 717-724$ (1992). 
36. H. EHRINGER and O. HORNYKIEWICZ, Wien. Klin. Wschr. 381236 (1960) .

37. M. CARLSSON and A. CARLSSON, J. Neural Transm. 75 221-226 (1989) .

38. M. CARLSSON and A. CARLSSON, J. Neural Transm. $\underline{77}$ 65-71 (1989) .

39. R.L. ALBIN, A.B. YOUNG and J.B. PENNEY, Trends Neurosci. 12 366-375 (1989).

40. H. BERGMAN, T. WICHMANN and M.R. DELONG, Science 249 14361438 (1990).

41. I.J. MITCHELL, C.E. CLARKE, S. BOYCE, R.G. ROBERTSON, D. PEGGS, M.A.SAMBROOK and A.R. CROSSMAN, Neuroscience $\underline{32} 213-$ 226 (1989).

42. T. KLOCKGETHER and L. TURSKI, Trends Neurosci. 12 285-286 (1989) .

43. J.M. BROTCHIE, I.J. MITCHELL, M.A. SAMBROOK and A. CROSSMAN, Mov. Disord. 6 133-138 (1991).

44. T. KLOCKGETHER and L. TURSKI, Ann. Neurol. 28 539-546 (1990).

45. W.J. SCHMIDT and B. BUBSER, Pharmacol. Biochem. Behav. 32 621-623 (1989).

46. A.K. MEHTA and M.K. TICKU, Life Sci. 46 37-42 (1990).

47. T. KLOCKGETHER, L. TURSKI, T. HONORE, Z. ZHANG, D.M. GASH, R. KURLAN and J.T. GREENAMYRE, Ann. Neurol. 30 717-723 (1991).

48. P.-A. LÖSCHMANN, K.W. LANGE, M. KUNOW, K.J. RETTIG, P. JÄHNIG, T. HONORE, L. TURSKI, H. WACHTEL, P. JENNER and C.D. MARSDEN, J. Neural Transm. (Park. Dis. Dement. Sect.) $\underline{3}$ 203213 (1991).

49. A.R. CROSSMAN, D. PEGGS, S. BOYCE, M.R. LUQUIN and M.A. SAMBROOK, Neuropharmacology 28 1271-1273 (1989).

50. S.P. CLOSE, P.J. ELLIOT, A.G. HAYES and A.S. MARRIOTT, Psychopharmacology $\underline{102}$ 295-300 (1990).

51. C.D. MARSDEN and J.D. PARKES, Lancet I 292-296 (1976).

52. W. DANIELCZYK, Med. Welt 241278 (1973).

53. W. WESEMANN, G. STURM and E.W. FÜNFGELD, J. Neural Transm. Suppl. 16 143-148 (1980).

54. J.S. KIM, H.H. KORNHUBER, W. SCHMID-BURGK and B. HOLZMÜLLER, Neurosci. Lett. 20 379-382 (1980).

55. P. RIEDERER, K.W. LANGE, J. KORNHUBER and W. DANIELCZYK, Lancet $\underline{338}$ 1022-1023 (1991). 